\title{
方向抵抗特性を有する管路の 海永交換促進効果の検討 \\ STUDY ON EFFECTS OF THE SPECIFIC PIPE WITH DIRECTIONAL RESISTANCE PROPERTIES ON SEAWATER EXCHANGE
}

\author{
朴童津 1 - 堤啓 2 - 藤田和夫 3 - 小松利光 4 \\ Donjin PARK, Kei TSUTSUMI, Kazuo FUJITA and Toshimitsu KOMATSU \\ 1 正会員 工修 九州大学大学院学術研究員 工学研究院環境都市部門 (广812-8581 福岡市東区箱崎 6-10-1) \\ 2正会員 工修 国土交通省技官 北陸地方整備局 （T921-8042金沢市泉本町5-85） \\ 3 正会員 九州大学大学院技官 工学研究院環境都市部門 ( ₹ 812-8581 福岡市東区箱崎 6-10-1) \\ 4 フエロー 工博 九州大学大学院教授 工学研究院環境都市部門 (同上)
}

\begin{abstract}
The water in the pipe installed in a breakwater flows back and forth because of waves and a tidal current, so that if wall roughness with directional resistance properties is established in the pipe, the roughness behaves differently in response to the direction of flow. As a result, an one-way residual flow is produced and contamination in the port is swept away to the outer sea, and the water quality in the port is expected to be improved rapidly. In this paper, it was tried to make an one-way residual flow across the breakwater in the port by using a pipe with particular devised shape of wall roughness. At first, a square pipe with the Wall Roughness which has directional resistance properties was examined experimentally. Next, 2-dimensional numerical simulations were carried out to estimate the validity of this method in a model port. From these results, it becomes clear that this method can make an one-way residual flow and is quite efficient to improve the water quality in a semi-closed port.
\end{abstract}

Key Words : seawater exchange, directional resistance property, water purification, One-way pipe

\section{1. 目的}

港湾の多くは，静穏域を確保する目的から外海と 防波堤によって遮られ，閉鎖性の強い水域となって いる. そのため陸域から港内への流入水の水質が悪 化して負荷量が増加すると, 港内の富栄養化が進む ことが大きな問題となっている.これに対し，これ までは発生源対策に力が注がれてきたが，近年は開 口管を用いた透過式防波堤など，流動に着目した水 質改善手法を適用するケースが多く見られるように なってきた(1，2，3，4).

著者らは，潮汐や波浪によって生じる開口管内 の往復流に対し, 流れの方向によって異なる抵抗 を発揮する構造物（以後, 粗度と呼ぶ）を図-1の ように管壁に設置することで，管内に一周期平均 で港外から港内へ向かう一方向流れを形成し，港 内の海水交換を促進させる手法を提案している ${ }^{5)}$. 本論文では，その技術の実用化に向けた研究の成
果を報告する．まず，正方形断面の管の内壁に粗 度を設けた管路の害験により，方向抵抗特性を有 する管路（以後, One-way Pipe と呼ぶ）の基本水理 特性を明らかにした。次に, 模型湾や実海域を対 象とした数值シミュレーションにより One-way Pipe の有効性について検討を行った.

\section{2.凸型粗度を有する正方形One-way Pipe の 抵抗特性に関する実験}

以前行った開水路を用いた 2 次元の粗度実験の 結果から, 水路底面より窪んだ形の凹型粗度に比 ベ，水路壁面より突出した凸型粗度の方が流れの 向きによる抵抗差が 1 オーダー近く大きいことが 確認されている ${ }^{6)}$. そこで, 流れの方向による抵抗 差が大きい凸型粗度形状のうち, 比較的形状が単 純な $1 / 4$ 円柱型粗度を正方形管内に設置し，その抵 抗特性について調べた。 


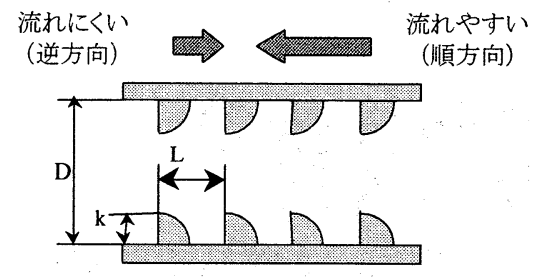

図-1＼cjkstart粗度の設置状況

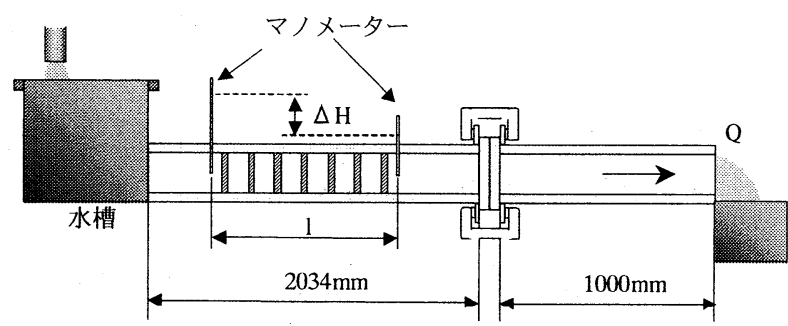

図-2 実験装置の概略

表-1 実験条件

\begin{tabular}{|r|r|r|r|}
\hline 粗度高さ $k(\mathrm{~mm})$ & \multicolumn{1}{l|}{$L / k$} & 粗度個数 & 損失水頭測定区間 $(\mathrm{mm})$ \\
\hline 6 & 3 & 37 & 762 \\
\hline 6 & 6 & 19 & 762 \\
\hline 6 & 9 & 13 & 762 \\
\hline 6 & 12 & 10 & 762 \\
\hline 6 & 18 & 7 & 762 \\
\hline 9 & 3 & 37 & 1143 \\
\hline 9 & 6 & 19 & 1143 \\
\hline 9 & 9 & 13 & 1143 \\
\hline 9 & 12 & 10 & 1143 \\
\hline 9 & 18 & 7 & 1143 \\
\hline 12 & 3 & 37 & 1524 \\
\hline 12 & 6 & 19 & 1524 \\
\hline 12 & 9 & 13 & 1524 \\
\hline 12 & 12 & 10 & 1524 \\
\hline 12 & 18 & 7 & 1524 \\
\hline 14 & 3 & 37 & 1778 \\
\hline 14 & 6 & 19 & 1778 \\
\hline 14 & 9 & 13 & 1778 \\
\hline 14 & 12 & 10 & 1778 \\
\hline 14 & 18 & 7 & 1778 \\
\hline \hline
\end{tabular}

\section{（1）実験装置および方法}

図 - 2 に実験装置の概略を示す．内壁に $1 / 4$ 円柱型 粗度を設置した一辺の長さが $10 \mathrm{~cm}$, 全長約 $300 \mathrm{~cm}$ の 正方形管を水槽底部に取り付け，水槽側から水を供 給することによって管内に流れを形成した。管内の 流れが定常になったのを確認した後，粗度設置区間 の損失水頭 $\Delta \mathrm{H}$ およびその時の流量 $\mathrm{Q}$ をマノメー ターおよび流量測定容器によってそれぞれ測定した. 各実験 Case における粗度の設置状況は, 粗度高さ $\mathrm{k}$ と設置間隔 $\mathrm{L}$ の関係によって表 -1 のように変化させ た. 実験における Reynolds 数は $3 \times 10^{4} \sim 1 \times 10^{5}$ で あった.ここで, 図-1 中の流れやすい方向を順方向, 流れにくい方向を逆方向と定義し，また $\mathrm{k}$ は粗度高 さ, Lは設置間隔, D は正方形断面の一辺の長さであ る. なお，一方向の流れに対する一連の測定を終え
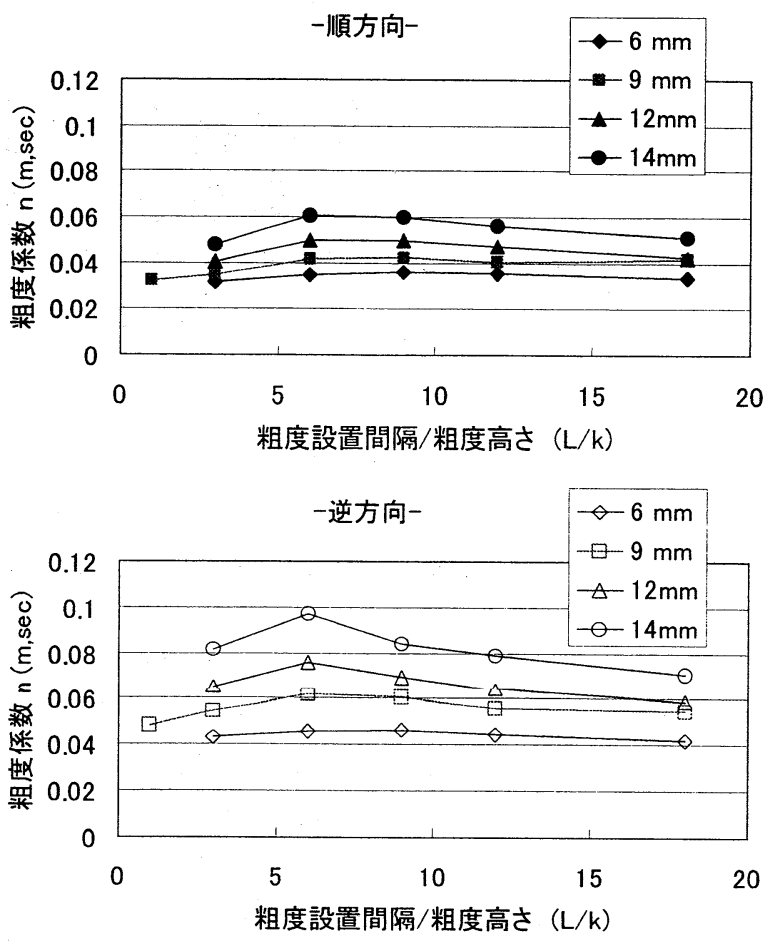

図-3 粗度係数と $\mathrm{L} / \mathrm{k}$ の関係
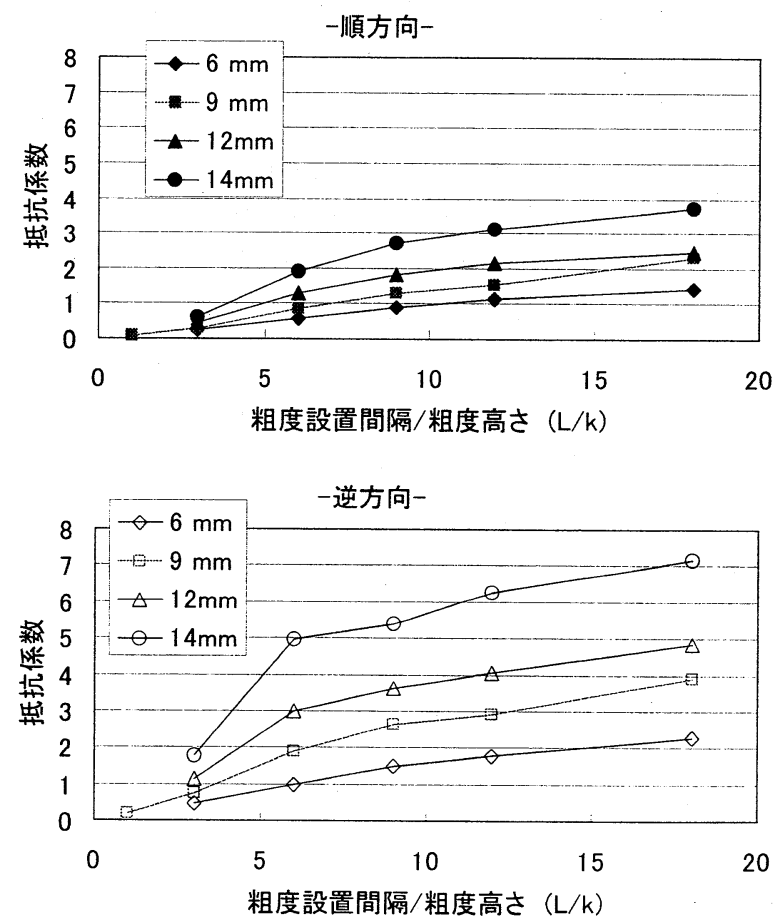

図-4 抵抗係数と $\mathrm{L} / \mathrm{k}$ の関係

た後に管を逆向きに取り付けることによって，逆方 向の流れに関する測定を行った。

\section{（2）壁面抵抗の特性値}

測定結果を用いて, $\mathrm{n}=\mathrm{AR}^{2 / 3} \mathrm{I}^{1 / 2} / \mathrm{Q} よ り$ Manninng の粗度係数 $\mathrm{n}$ を算出した。ここで， $\mathrm{A}$ ：正方形管断 面積 $\mathrm{D}^{2}\left[\mathrm{~m}^{2}\right], \mathrm{R}$ : 径深 $[\mathrm{m}], \mathrm{I}$ : 動水勾配, $\mathrm{Q}$ : 流量 $\left[\mathrm{m}^{3} /\right.$ $\mathrm{sec}$ ]である. 図 -3 に $\mathrm{L} / \mathrm{k}$ と粗度係数の関係を示す. 


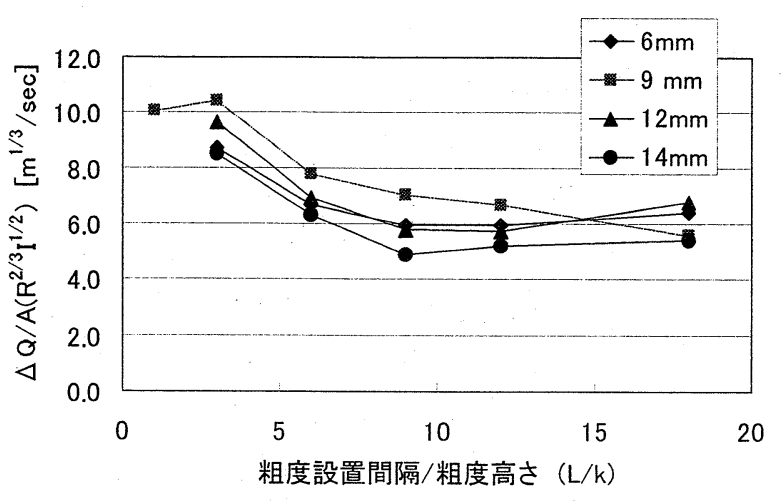

図-5 $\Delta Q / A R^{2 / 3} I^{1 / 2}$ と $\mathrm{L} / \mathrm{k}$ の関係

順・逆方向ともに粗度高さ $\mathrm{k}$ が大きいほど粗度係数 の值は大きいことが分かる。これは $\mathrm{k}$ が大きいほど 管の断面積を減少させ，流れを阻害する効果が大 きくなるためである.

$\mathrm{L} / \mathrm{k}$ の違いによる粗度係数の変化を見ると, 順 方向の流れに対しては $\mathrm{L} / \mathrm{k}=6 \sim 9$ で, 逆方向の流れ に対しては $\mathrm{L} / \mathrm{k}=6$ 程度で粗度係数は最大值を持つこ とが分かる. 群粗度の場合, 粗度を密に設置し過 ぎると粗度の相互干渉のためにその抵抗は減少し， 逆に疎になり過ぎると抵抗の主な発生要因である 粗度の密度が小さくなるため抵抗は同じく減少す る. 本実験結果において順方向と逆方向とで最大 值を示す $\mathrm{L} / \mathrm{k}$ が異なることから，1/4 月柱型粗度は 順方向と逆方向とで正方形管内壁に設置した場合 の群粗度としての性質に違いがあることが分かる.

また，管内に設置した粗度の抵抗を管路壁面のせ ん断応力に置き換えることによって, 粗度の抵抗係 数を,

$$
C_{d}=\frac{8 D g R \Delta H}{N\left(D^{2}-d^{2}\right) U^{2}}
$$

より算出し，L $/ \mathrm{k}$ との関係をまとめた（図 -4).こ こで, $\mathrm{C}_{\mathrm{d}}$ : 粗度一枠の抵抗係数, $\Delta \mathrm{H}$ : 粗度設置区 間に打ける損失水頭, $\mathrm{N}$ : 粗度の設置個数, $\mathrm{d}$ : 粗 度頂部での正方形管の一辺の長さ (=D-2k), U : 断面 平均流速である. この結果より， $\mathrm{L} / \mathrm{k}$ が大きくなる につれて抵抗係数がある值に漸近する形で増加す る傾向が読み取れる。これは $\mathrm{L} / \mathrm{k}$ が大きいと上流側 に設置された粗度による流れの遮蔽効果が小さく なるためで，抵抗係数の值は粗度が単体で管内に 設置されたときに発揮する值へと漸近しているも のと考えられる.

（3） One-way Pipe の海水交換促進効果に関する検討 One-way Pipe においては，流れの向きによって異な る抵抗を発揮し, 往復流に対して一周期平均でより 強い一方向流机を形成することが重要である，従っ て，いくら抵抗差が大きくても抵抗の絶対值が大き

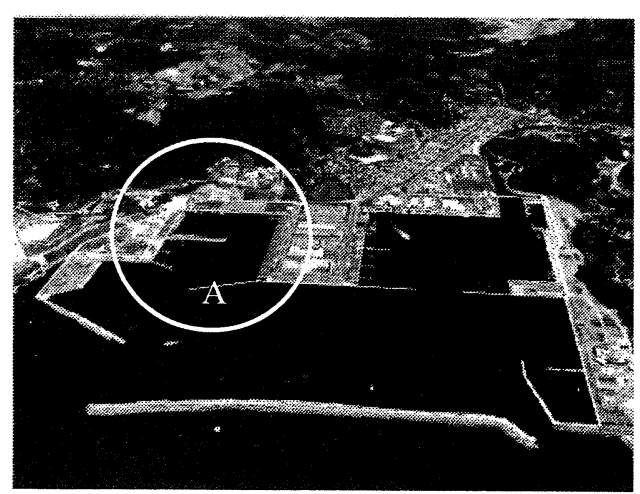

図-6 新長崎漁港

表-2 One-way Pipe の諸値

\begin{tabular}{|l|l|r|}
\hline \multirow{2}{*}{ 形状損失係数 } & 入口 $\zeta_{\mathrm{e}}$ & 0.5 \\
\cline { 2 - 3 } & 出口 $\xi_{\mathrm{o}}$ & 1 \\
\hline コンクリート壁面の粗度係数 $\mathrm{n}[\mathrm{m}, \mathrm{sec}]$ & & 0.012 \\
\hline 矩形管の内径 $\mathrm{D}[\mathrm{m}]$ & & 2 \\
\hline 管路長さ $\mathrm{L}[\mathrm{m}]$ & & 10 \\
\hline 粗度高さ $\mathrm{k}[\mathrm{m}]$ & & 0.2 \\
\hline 粗度間隔 $(\mathrm{l} / \mathrm{k})$ & & 3 \\
\hline 抵抗係数 $\mathrm{C}_{\mathrm{D}}$ & 順方向 & 0.302 \\
\hline 逆方向 & 0.741 \\
\hline 粗度設置個数 $\mathrm{N}$ & & 16 個 \\
\hline
\end{tabular}

ければ管内でのエネルギー損失が大きくなり，Pipeを 通過する流量は減少するため, 海水交換の促進を目 的とする One-way Pipe としての効果は小さくなる.

順流と逆流とで動水勾配が等しい場合の流量差 の無次元量

$$
\triangle Q / A R^{2 / 3} I^{1 / 2}=\frac{1}{n_{1}}-\frac{1}{n_{2}}
$$

を一方向流れの生成能力を表す一つのパラメーター として考えることができる. ここで, $\mathrm{n}_{1}$ ：順方向の粗 度係数, $\mathrm{n}_{2}$ : 逆方向の粗度係数である. 図 -5 は上式 より算出された $\Delta \mathrm{Q} / \mathrm{AR}^{2 / 3} \mathrm{I}^{1 / 2}$ の值と $\mathrm{L} / \mathrm{k}$ との関係を示し たものである。この図からいずれの粗度高さにおい ても粗度設置間隔が狭いはど流量差が大きく, 中で も $\mathrm{k}=9 \mathrm{~mm}$ のときに $\Delta \mathrm{Q} / \mathrm{AR}^{23} \mathrm{I}^{1 / 2}$ の值は大きいことが分 かる. 今回得られた結果では $\mathrm{k}=9 \mathrm{~mm}$ 以外では $\mathrm{L} / \mathrm{k}=1$ に ついての結果がないので, いずれの粗度高さにおい ても流量差が $\mathrm{L} / \mathrm{k}=3$ で最大值を持つと言いにくいが その傾向は $\mathrm{k}=9 \mathrm{~mm}$ に似ていると考えられる. 従って, 正方形管においては一辺の長さの一割程度の高さを もつ粗度を $\mathrm{L} / \mathrm{k}=3$ 程度の間隔で管内に設置した場合に 一方向流れの生成能力は最も大きいと推測できる.

3. 数值シミュレーションによる One-way Pipe の海水交換促進効果の検討

\section{（1）模型湾を対象とした数值実験}

長崎県西彼杵半島に位置する新長崎漁港は, 長大 


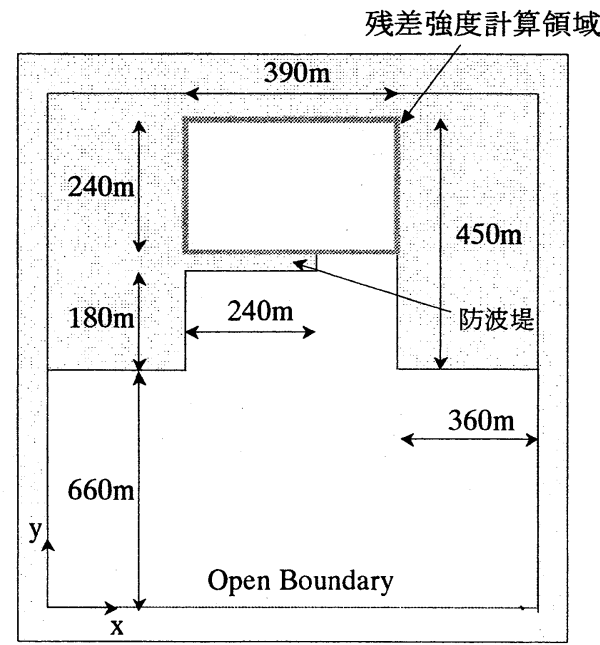

図-7 モデル湾の概略図

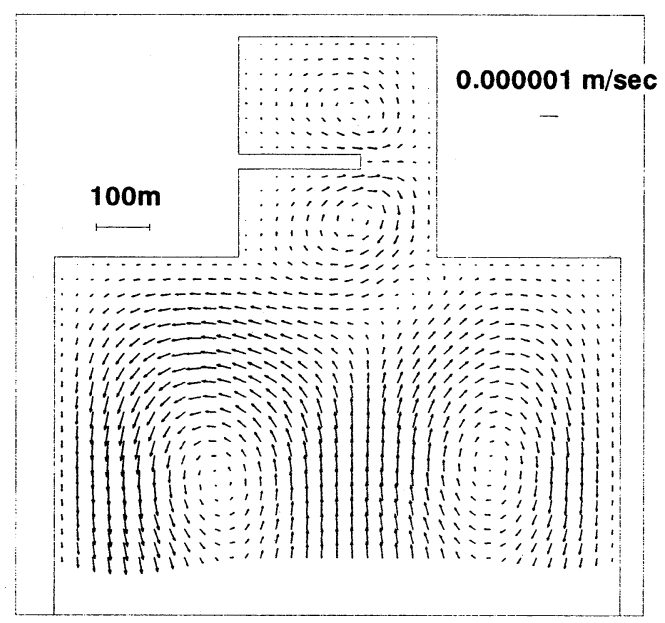

図-8 残差流 : One-way Pipeなし (Case-0)

な防波堤に囲まれた典型的な閉鎖性港湾である（図一 6). 特に, 港奥の A の領域はその閉鎖性のために水質 が悪化している．そこで領域 A とスケールが同じで あり, 水深が $10 \mathrm{~m}$ で一定としたモデル湾（図 -7）に おいて, 潮汐流に対する One-way Pipe の効果について 数值計算による検討を行った.

計算は ADI 法による平面 2 次元潮流計算および拡 散計算である. 図-7 の開境界で $\mathrm{M}_{2}$ 分潮を与え, 潮 位変動振幅を $25 \mathrm{~cm}$, 渦動粘性係数を $20 \mathrm{~m}^{2} / \mathrm{s}$, コリオ リ係数を 0 , 海底摩擦係数を 0.0026 とした. また, メッシュ間隔は $\Delta \mathrm{x}=\Delta \mathrm{y}=30 \mathrm{~m}$ とし, 潮流計算に対 しては $\Delta \mathrm{t}=1.0 \mathrm{sec}$ ，拡散計算に対しては $\Delta \mathrm{t}=10 \mathrm{sec}$ とした. One-way Pipe は, 港内と港外を結ぶよう に防波堤内に設けられることを想定しており, 計 算においては潮位変動に伴う防波堤前後の水位差 だけによって管内に海水が流入するものと仮定し た。つまり，防波堤を挟んで港外側のメッシュ（添 字 1) と港内側のメッシュ（添字 2) の水位差 $\Delta \mathrm{H}$ $\left(=\left|\mathrm{H}_{1}-\mathrm{H}_{2}\right|\right)$ によって One-way Pipe を通過する流量 $\mathrm{Q}$,

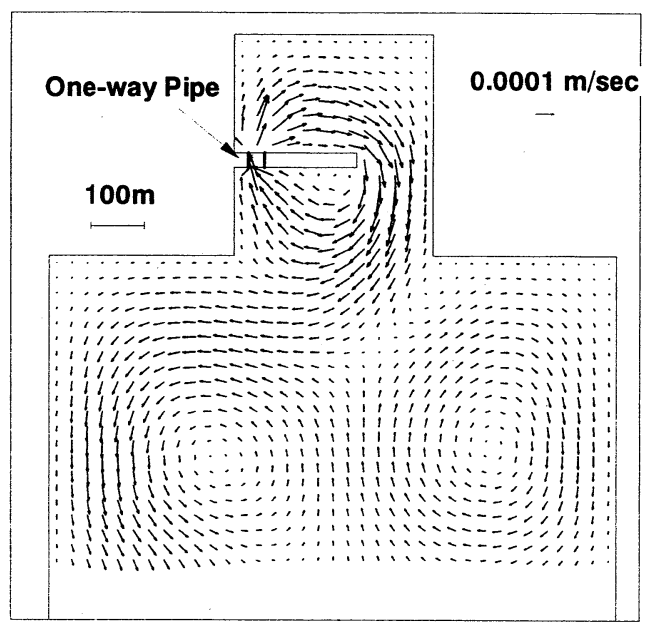

図 -9 残差流: One-way Pipe あり(Case-3)

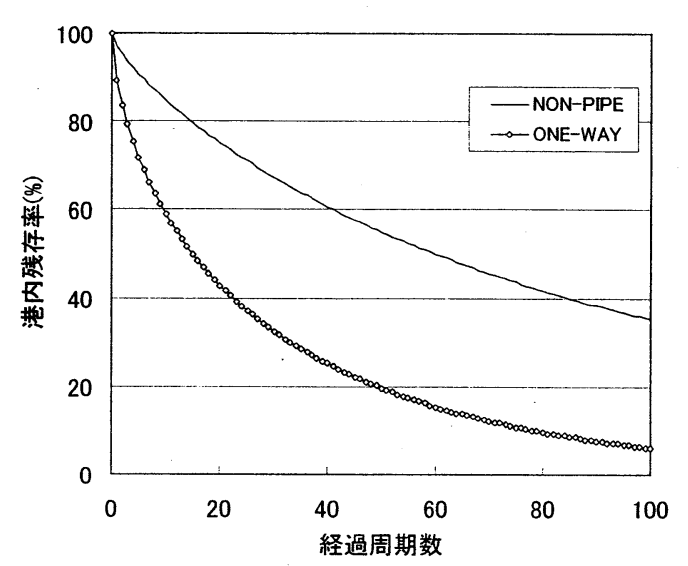

図-10 港内残存率の比較

$$
Q=\frac{A \sqrt{2 g \Delta H}}{\sqrt{\left\{\zeta_{e}+f_{1} \frac{l}{D}+\frac{N\left(D^{2}-d^{2}\right) C_{d}}{4 D R}+\zeta_{o}\right\}}}
$$

により算出し, 連続の式の中へ組み込んだ.ここで, $\zeta_{\mathrm{e}}$ : 管の入口損失係数, $\zeta_{0}$ : 管の出口損失係数, $\mathrm{f}_{1}$ : 管路材料による摩擦損失係数, 1: One-way Pipe の長 さ, $\mathrm{d}$ : 粗度頂部での正方形の一辺の長さ $(=\mathrm{D}-2 \mathrm{k})$, $\mathrm{A}$ : 正方形管の断面積, $\mathrm{C}_{\mathrm{d}}$ : 粗度一枠の抵抗係数, $\mathrm{N}$ : 粗度の設置個数であり，それぞれ表-2 に示す值を 設定した．また，Pipe で結ばれているメッシュにお ける運動量の変化は小さいと仮定して無視した.

まず，比較対象用として One-way Pipe を適用し ないケースについて計算を行なったところ，残差 流の大きさは極めて小さく, 港内と港外でそれぞ れ閉じた環流を形成していることがわかった(図 8). 次に, 図 -7 中の防波堤の付け根から 3 メッシュ 目にOne-way Pipeを 1 本組み込み, 計算を行なっ た. 図ー9 は残差流の計算結果を示したものであり , Pipe から流入した海水が港口から流出し, 港外と 港内を結ぶ大きな環流が形成されていることが見 て取れる。 また, 港内に初期濃度として一様濃度 


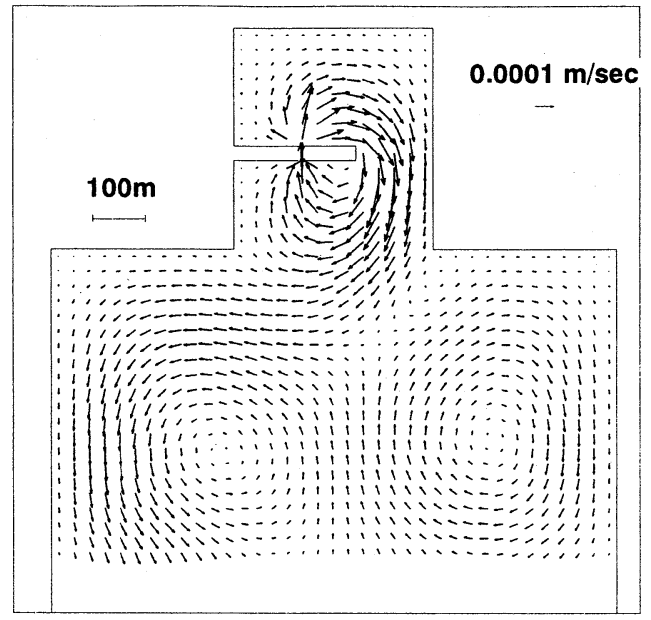

図-11 残差流 : One-way Pipe あり (Case-6)

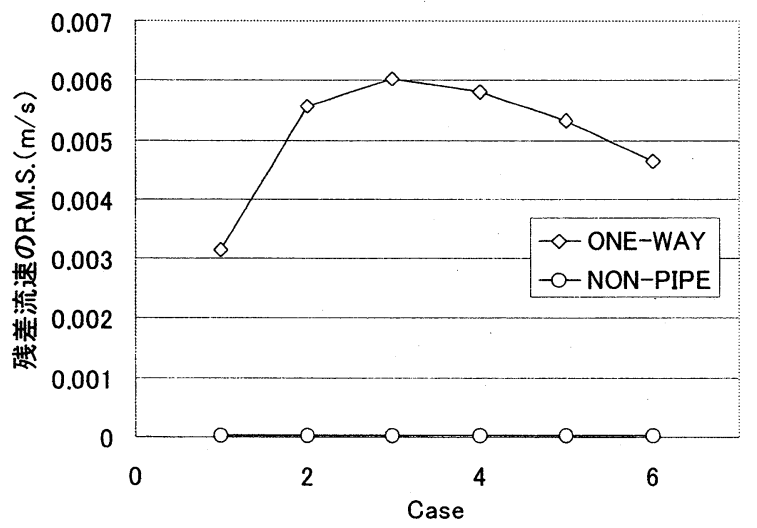

図-12 残差強度の比較

( $\mathrm{C}=10.0)$ の拡散物質を投入し, 港内残存率を求めた ところ, One-way Pipeを組み込んだ場合の方が残存 率の低下速度が大幅に速くなることが確認された (図 -10). このときの One-way Pipe 内の一潮汐平均 流速は $6.3 \mathrm{~cm} / \mathrm{sec}$ であった. 以上の結果より. Oneway Pipe を防波堤内に組み込むことによって港内の 海水交換を促進させうることが示唆された.

実海域において One-way Pipe を設置する場合, 設 置位置によって環流の規模に違いが生じ，それが港 内の海水交換に影響を及ぼすことが予想される。 そ こで, One-way Pipe を組み込む位置を変化させて計 算を行い, Pipeの設置位置の違いによる海水交換の 促進効果の変化について検討を行なった。計算は防 波堤の付け根から 1 〜 メッシュ目までのどれか一 つにOne-way Pipe 1 本組み込み(防波堤の付け根 側から Case1 〜 Case6 とする)，それぞれに対して計 算を行なった. また, 港内の残差流速の Root Mean Square（残差強度）を算出し, 港内残差流の強さに ついて検討を行った。図-11 はCase 6 における残差 流速パターンを示したものである. Case 6 と防波堤 の付け根側に One-way Pipe を組み込んだ Case 3 の計 算結果（図-9）を比較すると,Case 6 では湾奥部に おける残差流の生成規模が小さく, 港口付近に偏っ

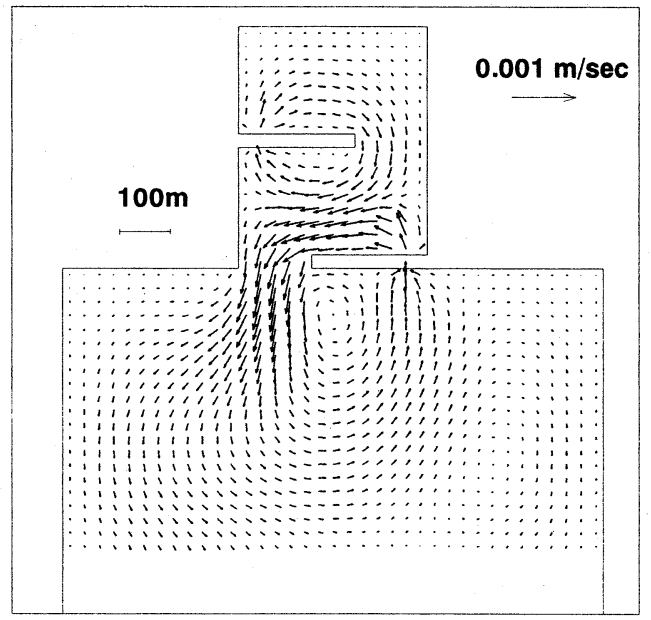

図-13 閉鎖度が強いモテル湾における残差流速 : One-way Pipe あり

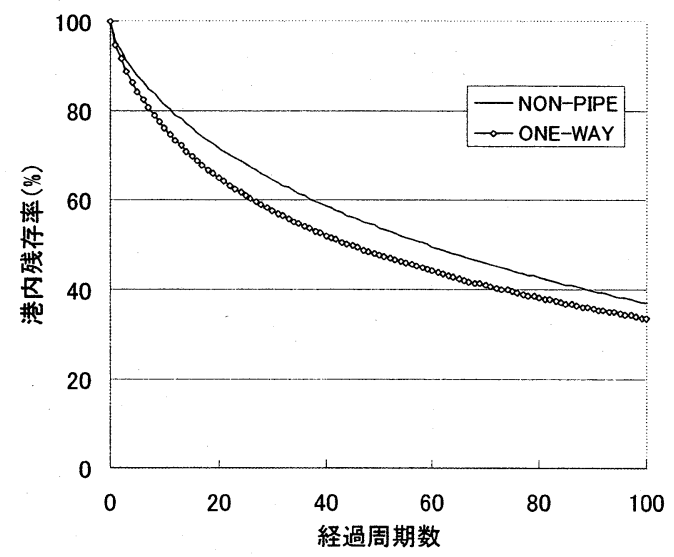

図-14 閉鎖度が強いモデル湾における 港内残存率の比較

た環流が形成されていることが分かる。また，港 内残差強度を比較した図-12 から, 管の設置位置 に上り港内残差強度に違いが見られることから， 実海域に適用する場合にはその設置位置について 十分な検討が必要であることが分かる.

さらに，閉鎖度がより強い港湾における効果に ついて検討を行うために, 新長崎漁港を参考にし て図-13 のような模型湾を対象に数值実験を行っ た.このような構造の海域の場合, 湾奥の海水交 換のためには防波堤(1)を囲む時計回りの還流と防 波堤(2)を囲む反時計回りの残差還流の生成が必要 となる. 防波堤(1)と(2)にOne-way Pipe を設置し, 計 算を行った. その結果を図-13 に示す. 2 つの残 差還流が生成されている. また，図－14 に示すよ うに拡散計算により湾奥における拡散物質の残存 率を調べたところ, One-way Pipe を各々 1 本ずつ 設けた場合の効果が確認された.

\section{（2）実海域を対象とした数值実験}

新長崎漁港全域を対象とした数值実験は, 潮 位変動振幅を $49 \mathrm{~cm}$, コリオリ係数を $8.3 \times 10^{-5} \mathrm{~s}$ 


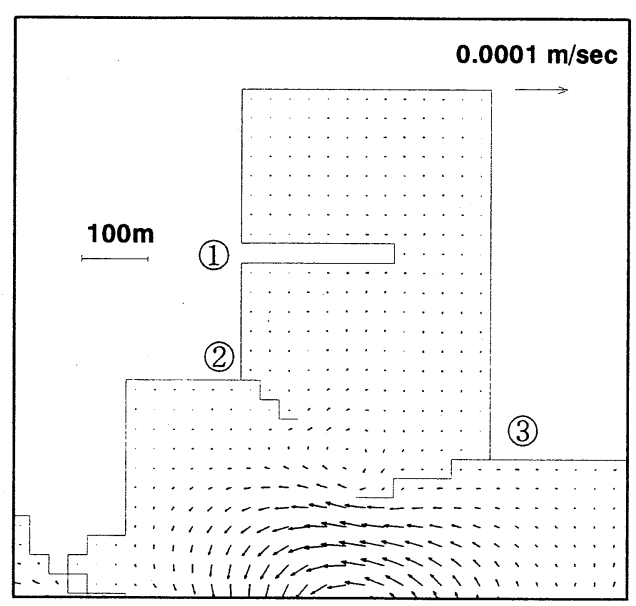

図-15 残差流速 : One-way Pipe なし

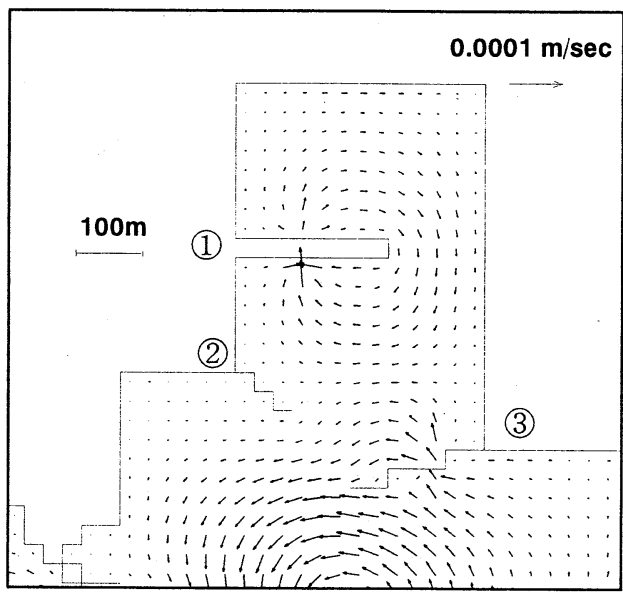

図-16 残差流速: One-way Pipe あり

', 水深を実際の水深, その他はモデル湾の計算に おける值と同じ值を用いて行なった. 図-15,16 は One-way Pipe の有無による残差流の違いを, 図-6 中の領域 $\mathrm{A}$ を拡大して示したものである. 図-16 においては防波堤(1)の付け根から 4 メッシュ目と ，防波堤(3)の付け根から 3 メッシュ目にOne-way Pipeを組み込んだ. One-way Pipeを組み込んでい ない図-15では領域 Aにおいてほとんど残差流が 生成されていないのに対し, 組み込んだ図-16に おいては防波堤(1)を跨ぐ時計回りの環流と, 防波 堤(3)を跨ぐ反時計回りの環流が形成されており， これらが港口付近で合流し，港外へと流出してい ることが確認できる。 その結果，湾奥部と外海と の海水交換が可能となり, 水質改善が進むことが 期待できる.

\section{4. 結論}

以上の結果をまとめると次のようになる.

1）正方形管内に $1 / 4$ 円柱型粗度を設置した One- way Pipe を用いて実験を行った結果, 順流と逆流 とで動水勾配が同じ往復流に対して, 管路内壁の 一辺の長さの 1 割程度の高さを持つ粗度を $\mathrm{L} / \mathrm{k}=3$ 程 度の間隔で設置したときに一方向流れの生成能力 がもっとも大きい.

2）平面 2 次元の潮流計算を行った結果, One-way Pipe を用いることによって港内に一方向流れを創 造することができ, One-way Pipe は海水交換の促進 に対して有効であることが明らかになった。

3） One-way Pipe は, 防波堤での設置位置によって その効果が異なってくるため, 実海域へ適用する 際には十分な検討が必要である. また One-way Pipe の組み合わせにより閉鎖性が強い海域における海 水交換効果も期待できる.

今回は潮位変動のみを駆動力としたが，実際は 波も往復流を生成するため波の効果もおおいに期 待できる. また, One-way Pipeの入口をベルマウス 型などの入口損失の少ない形状に, 出口を防波堤 から突き出させて逆流時の入口損失を大きくして やることにより, 順・逆流時の抵抗差をより大きく することも可能であることから, 実際に本Pipe を 適用した場合はより大きな効果が期待できるもの と思われる。

追記 : 本研究は丸栄コンクリート工業 (株) との共 同研究として行われたものである.

\section{参考文献}

1）山本 潤-武内智行 - 中山哲嚴 - 田畑真一・池田正信 : 志賀島漁港外港の導水工による環境改善効果に関する現 地調査, 海岸工学論文集, 第 41 巻, pp. 1096-1100

2）下迫健一郎・近藤充隆・藤堂ひろみ・福井正幸・高橋重 雄:越波造流型海水交換防波堤の開発とその水理特性, 海岸工学論文集, 第 46巻, pp. 1096-1100

3）森田修二・出口一郎: スロープ水路を有する透過性防波 堤に関する研究, 海岸工学論文集, 第 46 巻, pp. 11011105

4）西守男雄・日比野忠史・鶴谷広一・石原弘一：実海域に おける下部透過型防波堤の海水交換特性, 海岸工学論文 集, 第 46 巻, pp. 1081-1085

5）朴童津・堤啓・佐々木亨・小松利光: 方向抵抗特性を有 する 2 次元粗度に関する実験的研究, 水工学論文集, 2002 年 2 月, 第 46 巻, pp. $463-468$

6）小松利光・小橋乃子・田嶋健太郎・藤田和夫·安達貴浩・ 矢野真一郎・末松吉生・甲斐一洋: 底面粗度を用いた海 域の水質改善技術の実用化へのアプローチ, 水工学論文 集, 2000 年 3 月, 第 44 巻, pp. 957-962

（2002. 9. 30受付） 